\title{
An Ecological Survey of Limoniastrum guyonianum: A Halophyte Native Tree in Arid Zones of Algeria
}

\author{
Chafi Mohammed El Habib, Selkh Chouaib and Bensoltane Ahmed \\ Department of Biology, Faculty of Sciences of Nature and the Life, University of Ahmed Ben Bella-Oran1, City of Oran 31000, \\ Algeria
}

\begin{abstract}
In arid and semi-arid regions soil salinity is a constraint for the development of plants and a threat to balance food in these soils some species are threatened with extinction. Two natural constraints drought and salinity have altered the ecosystem stability, but it has always conditions more or less favorable to the existence of a spontaneous flora adapted to the climatic and edaphic stress. The aim of this study is to describe a halophyte native tree and its climatic and edaphic requirements, it is a case of Limoniastrum guyonianum. According to this survey L. guyonianum, grows well under high temperature, insolation and evaporation and low rainfall and humidity. The species tolerate the soil basic $\mathrm{pH}$, salinity, calcareous and do not need the organic matter and chlorure ions. There are some morphological adaptations in the L. guyonianium to the several conditions as the length of the root and cylindrical shapes of the leaves and their extraction of salt.
\end{abstract}

Key words: Arid, salinity, climatic, edaphic, Limoniastrum guyonianum.

\section{Introduction}

Climate change becomes increasingly restrictive for growth and development of plants in particular in semi-arid and arid areas [1]. Arid and semi-arid ecosystems constituted about $2 / 3$ (two thirds) of the earth's surface [2]. Two natural constraints, drought and salinity, have altered the ecosystem stability [3] and are largely the causes of land desertification [4].

Estimates of one total area represented by the soil salsodiques the world varies greatly from one author to another: for Ref. [5], it reached 954.832 billion hectares, for Ref. [6] the area is estimated at about 9.55 million $\mathrm{km}^{2}$ or $6.4 \%$ of continents. There are 16 million of hectares of saline soils in the Mediterraneen pond whose 3.2 million of hectares are in Algeria [7].

In arid and semi-arid regions, these ecosystems are marked by rigorous and frequently drought, soil salinization is one of the main factors limiting the development of plant. The salinity is a major constraint to productivity and agricultural

Corresponding author: Chafi Mohammed El Habib, doctorat, research fields: nature and the life. development $[8,9]$. In these soils, some species are threatened with extinction [10]. Under these conditions plant morphology and physiology are disturbed $[11,12]$, some wild species have disappeared, others are endangered. The rehabilitation of a saline environment depends on the successful establishment of a vegetative cover. Depending on site conditions, herbaceous, plants shrubs or trees can adapt to it. On the most difficult sites, it may be necessary to use pioneer species to improve the site. Among the species which developed in saline zones in Algeria Linoniastrum guynianum has been used in traditional medicines to treat gastric infection. It has also been employed as an anti-bacterial drug in the treatment of bronchitis [13].

This study is description of Limoniastrum guyonianum - a halophyte and endemic tree suggested to rehabilitation of the saline environment in north of Algeria. The idea of introduction of fodder shrubs and the use of those indigenous resistant to aridity was adopted since 1920, as one of the ways for the restoration of degraded soils in Western Asia and North Africa [14]. 


\section{Materials and Methods}

\subsection{Locality of Linoniastrum guynianum}

Linoniastrum guynianum comes from the forest of Bel Ghazi which is located in Aougrout $30 \mathrm{~km}$ from
Timimoun Wilaya of Adrar (Fig. 1).

Studies in the present work include:

(1) Variations of five parameters (air temperature, rainfall, humidity, insolation and evaporation) of Timimoun, studied during a period of 10 years.

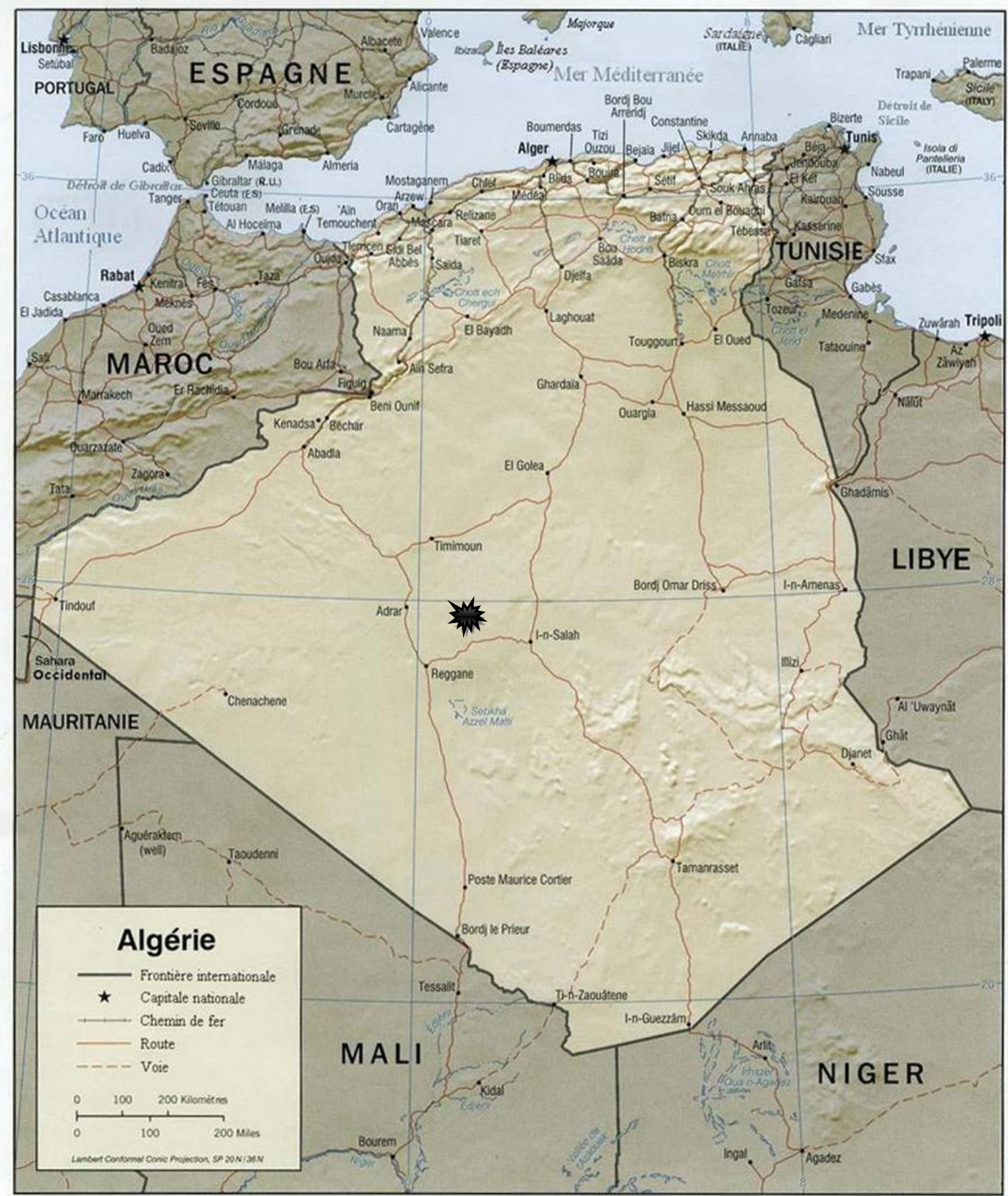

Rase 802562A1 (C00207) 8.01

Fig. 1 The geographical position station of the development of Limoniastrum guyonianum (south of Algeria).

\begin{tabular}{|l|l|}
\hline Geographical cordinates of Timimoun & $\begin{array}{l}\text { Latitude: } 29.25, \text { Longitude: } 0.25 \\
29^{\circ} 15^{\prime} 0^{\prime \prime} \text { North, } 0^{\circ} 15^{\prime} 0^{\prime \prime} \text { East }\end{array}$ \\
\hline area of Timimoun & 993,600 hectares \\
\hline Altitude of Timimoun & $281 \mathrm{~m}$ \\
\hline
\end{tabular}


(2) The physico-chemical analysis of a sample of soil which developed Limoniastrum guyonianum.

This analysis was effectuated in pedologic laboratory of soil department University of Mostaganem (Ex ITA) used the universal technic to determinate $\mathrm{pH}$, salinity, texture, calcareous active, chlorure sand organic matter.

(3) The morphology of Limoniastrum guyonianum and its development are described using the [15] flora document.

\section{Result}

\subsection{The Study of Climate Factors Which Developed} Limoniastrum guyonianum

Variations of the five parameters in a climate (temperature, insolation, evaporation, rainfall and humidity) of Timimoun during a period of 10 years are represented in Fig. 2. Climatic parameters of Timimoun show that Limoniastrum guyonianum growth in an arid climate is characterized by:

- Maximum temperatures reach $24.9{ }^{\circ} \mathrm{C}$ in January, $46.5{ }^{\circ} \mathrm{C}$ in July, and then they begin to decline to $23.7{ }^{\circ} \mathrm{C}$ in December. The same rate is observed for the average minimum temperatures, with $-0.4{ }^{\circ} \mathrm{C}$ in January, then it begins to increase to reach $22.3{ }^{\circ} \mathrm{C}$ in August to fall and reach $0.2{ }^{\circ} \mathrm{C}$ in December. Average monthly temperatures also vary with a minimum observed in December $\left(10.7{ }^{\circ} \mathrm{C}\right)$ and maximum $\left(34.1^{\circ} \mathrm{C}\right)$ in August.

- A low rainfall throughout the year with a dry period and the maximum of precipitation is situated in March with $3.8 \mathrm{~mm}$.

- A significant evaporation in July and August is $662 \mathrm{~mm}$ and $615 \mathrm{~mm}$ respectively, the minimum is calculated with $156 \mathrm{~mm}$ in January.

- A minimum isolation which is in February with 239 hours and the maximum in July with 326 hours.

- Relative air humidity varies between a maximum $51 \%$ in the month of December and a minimum of $16 \%$ in July.
3.2 The Physico-Chemical Analysis of Soil Which Develops Limoniastrum guyonianum

The analysis is shown in Table 1 below.

\subsection{Description of Limoniastrum guyonianum}

Limoniastrum guyonianum, its name in Arabic "Zeita" belongs to the family of Plumbiginacea, and is a shrub of $1.78 \mathrm{~m}$ high and $4.20 \mathrm{~m}$ wide (branches included) which grows on the dunes. It contains an average of 20 branches or twigs with $2-3 \mathrm{~cm}$ in diameter (Fig. 3). Its foliage is reminiscent of port Acacia radiana in adult stage, the branches sometimes tend to assume a horizontal position. In other individuals, they evolve trunk that splits into 2 or 3 parts which gives a false impression of the coexistence more individuals (Figs. $4 \mathrm{a}$ and $4 \mathrm{~b}$ ).

The leaves are cylindrical and measure $0.1-0.2 \mathrm{~cm}$ in diameter and 5-6 cm in length (Fig. 5). The foliage perfectly adapted to the dry conditions is protected by a waxy frame that reduces transpiration and protected plant against abrasive action of the sand particles which is carried by the wind. It is filled with concretions salts which have a form as white crystals of $1 \mathrm{~mm}$ diameter.

Flowers with purplish pink color, measuring 0.6-0.8 $\mathrm{mm}$, are combined united in branched clusters, consist of two fused bracts and evergreen, a chalice sepals welded, a corolla with five petals fused in the base and separate the upper part (Fig. 6). They are characterized by a pentameric symmetry protogymne. The fruits of Limoniastrumguyonianum are the capsules (Fig. 7).

The description of Limoniastrum guyonianum, shows well the adaptation of this species the conditions of water stress and salt that are considered as two limiting factors. Among these adjustment factors, the length of the main root sinking deep into the ground, the root system is very developed, in a seedling of $1.5 \mathrm{~cm}$; the main root reached $21 \mathrm{~cm}$ in length with laterals roots undeveloped. The cylindrical shapes of leaf limit the salt rejection as concretions flashing on leaves. 


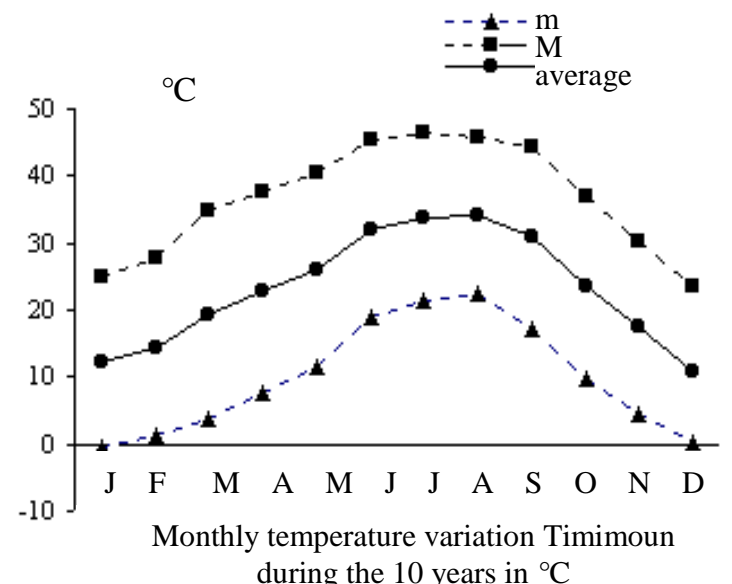

$\mathrm{m}$ : Temperature minimal

M: Temperature maximal $(\mathrm{m}+\mathrm{M}) / 2$ : average

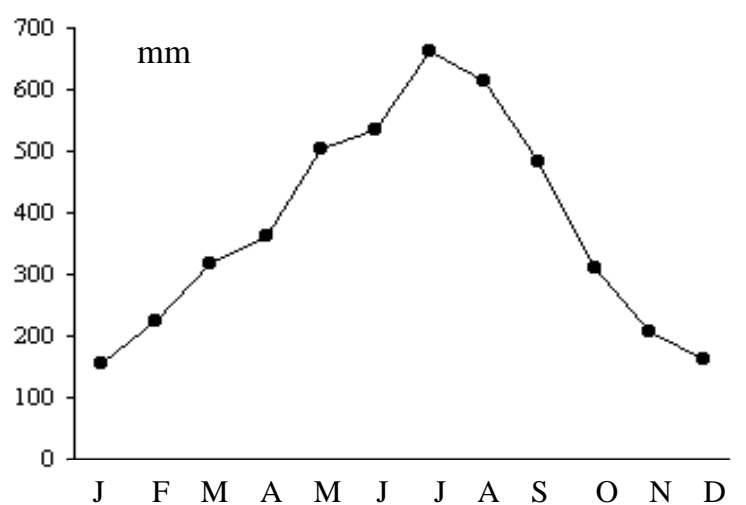

Monthly variation in evaporation Timimoun during 10 years in $\mathrm{mm}$

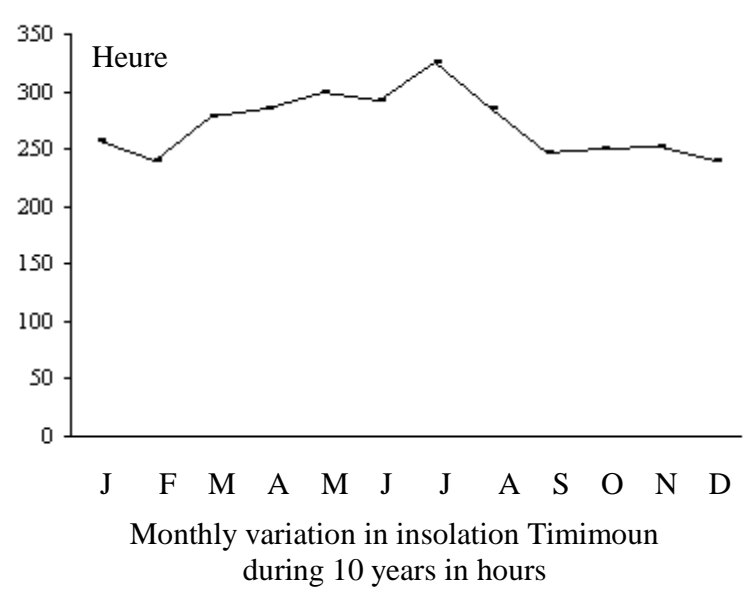

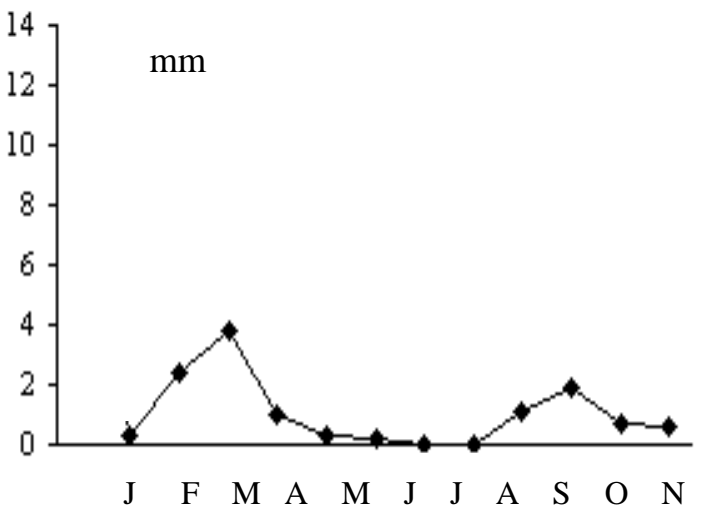

Monthly variation in rainfall in Timimoun during 10 years in $\mathrm{mm}$

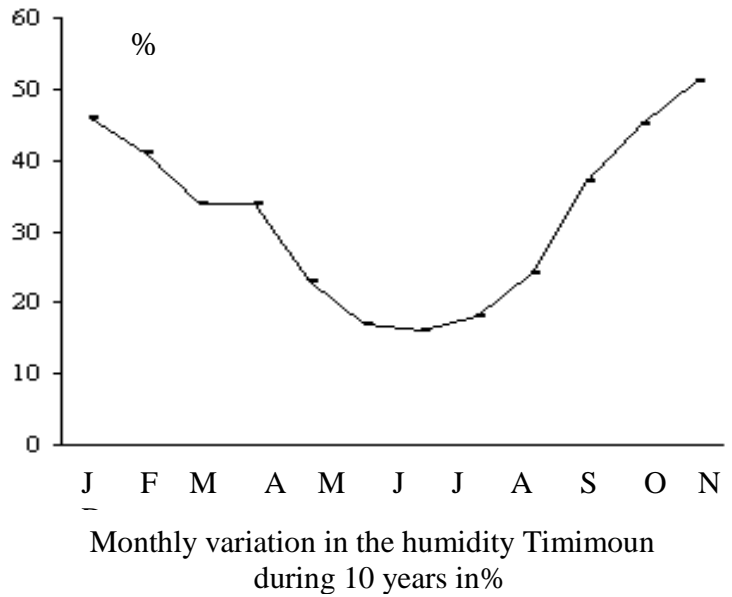

Fig. 2 Visualization of the climatic parameters of Timimoun station. 
Table 1 The results of the physicochemical analysis of the soil which develops Limoniastrum guyonianum.

\begin{tabular}{|l|l|}
\hline Coarsesand & $60 \%$ \\
\hline fine sand & $26.3 \%$ \\
\hline Clay & $3.2 \%$ \\
\hline Coarse silt & $5.6 \%$ \\
\hline $\mathrm{pH}($ water $)$ & $2.4 \%$ \\
\hline $\mathrm{pH}\left(\mathrm{CaCl}_{2}\right)$ & 8.50 \\
\hline $\mathrm{Salinity}$ & 7.88 \\
\hline $\mathrm{Cl}^{-}$ & $1.67 \mathrm{~ms}(\mathrm{mmhos} / \mathrm{cm})$ \\
\hline $\mathrm{CaCO}_{3}$ & $0.07 \mathrm{~g} / \mathrm{L}$ \\
\hline Active calcaeous & $6 \%$ \\
\hline Organiccarbon & $0.20 \mathrm{~g} / \mathrm{L}$ \\
\hline Organicmatter & $0.38 \%$ \\
\hline
\end{tabular}

\section{Discussion}

The values of parameters climatic of Timimoun show that the minimum temperatures correspond to the winter rest which is characterized by the month where minimum temperature is lower to $3{ }^{\circ} \mathrm{C}$ [16], on the other hand the maximum temperatures accentuate the water deficit by increasing the evaporation during the summer season (July and August).

Extreme temperatures cause phenomena of capillarity and the remonte salts that crystallize on the surface and lead the increase as concentrations saline rate salinity and increased physiological stress in plants, this high concentration in salt is fatal for non-halophytes rates.

The results of the physicochemical analysis of the soil which develops Limoniastrum guyonianum are shown in Table 1.

The saline soils are characterized by domination by the presence of high amounts of soluble salts, or the richness of absorbing ions from these salts and likely complex degrading of their characteristics and physical properties, particularly their structure, they make diffuse, these two characteristics of these soils modify and reduce the development of vegetation and crops that we can do.

From Table 1 we can conclude that Limoniastrum guyonianum grows on sandy soil with a basic $\mathrm{pH}$, salt and low in calcareous and organic matter.
In fact the $\mathrm{pH}$ is an indicator of soil reaction, saline soils have $\mathrm{pH}$ between 8 and 9 this means generally the limit of structure degradation $[17,18]$.

According to Ref. [19] the soil developed, $L$. guyonianum is weak in limestone and it is salt, this salinity is depending on the electrical conductivity of the aqueous extract at $25^{\circ} \mathrm{C}$.

Organic matter is an important source of nutrients for plants and the knowledge of its total content in the soil information on its aggregates formation.

The result also shows organic matter content $(0.81 \%)$ this percent is very low [20], the coarse sand is considered the largest mineral fraction of soil. About fertility, coarse sand does not contain nutrients for plants [21].

According to Ref. [22] the sand with no colloidal particles cannot play any role in the formation of stable aggregates in the soil.

In arid areas, harsh climate forcing plant species necessary for their survival adaptations these adaptations to environmental conditions and their mechanisms have been described in all plant groups [23]. They cover the morphological and physiological regulation that allows plants to adapt to a supply of water loss taking place at different scales.

Longer water deficits induce changes more irreversible, including morphology (reduction of evaporation surfaces). 


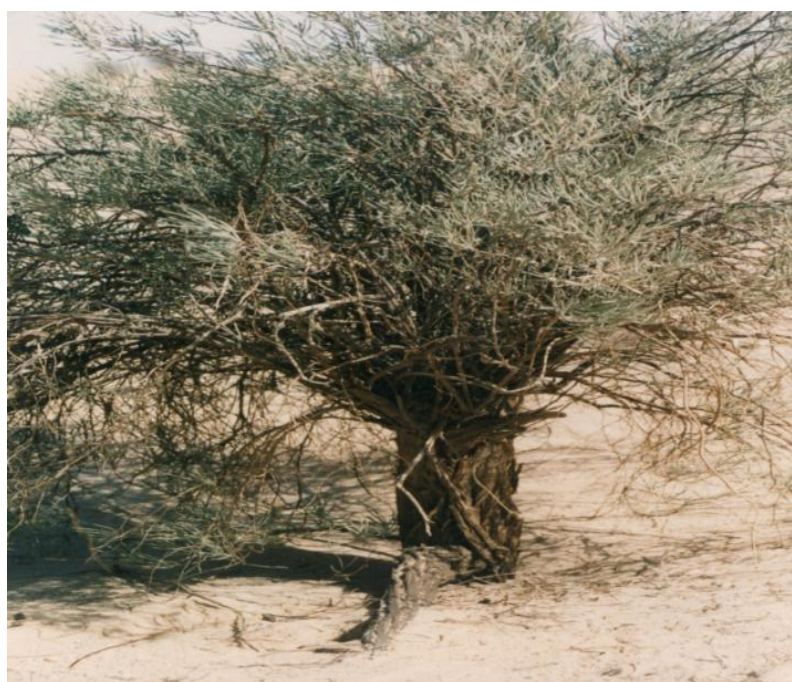

Fig. 3 Morphology of Limoniastrum guyonianum: individual tree.

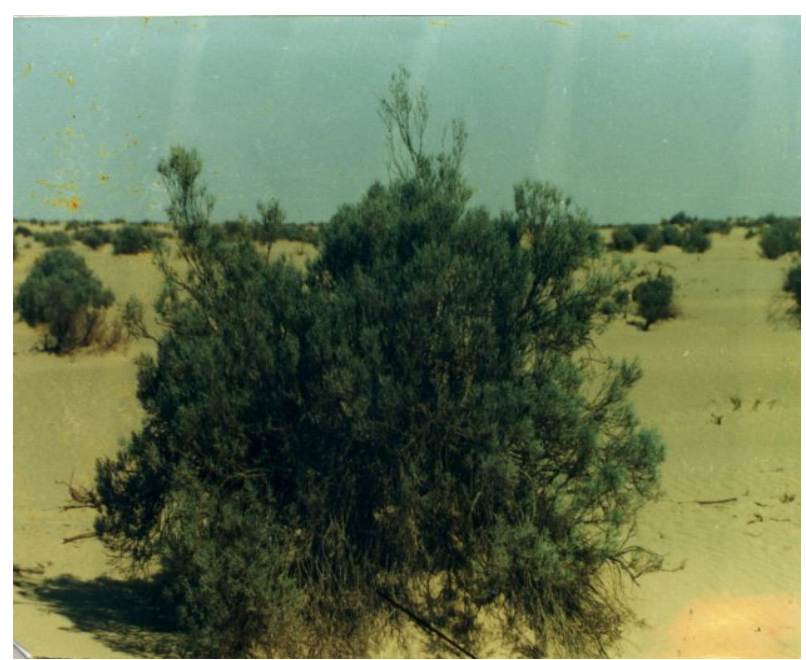

Fig.4a Limoniastrum guyonianum tree gives a false impression of the coexistence more.

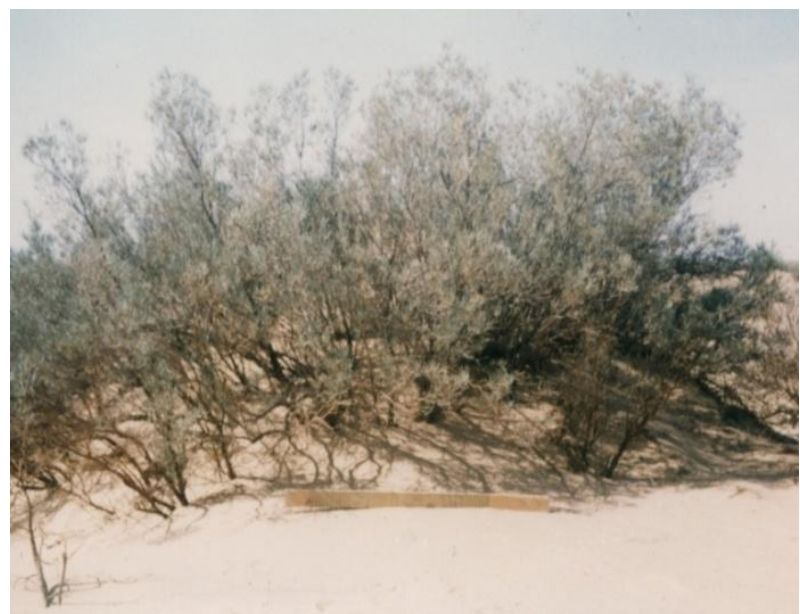

Fig. 4b Limoniastrum guyonianum tree gives a false impression of the coexistence more.

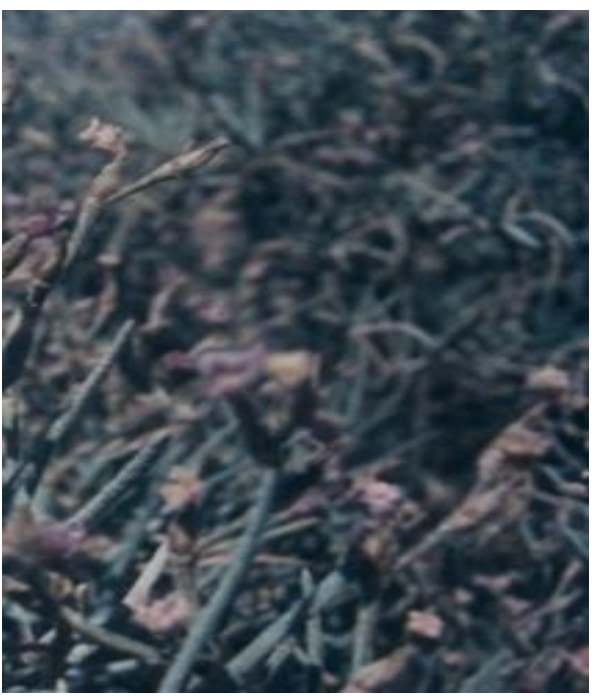

Fig. 5 Morphology of the Limoniastrum guyonianum leaves.

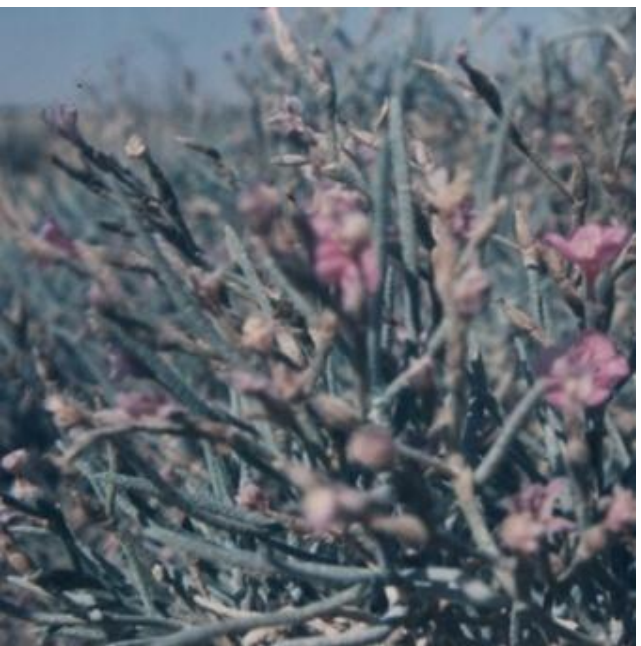

Fig. 6 Flowers are purplish pink colorin Limoniastrum guyonianum.

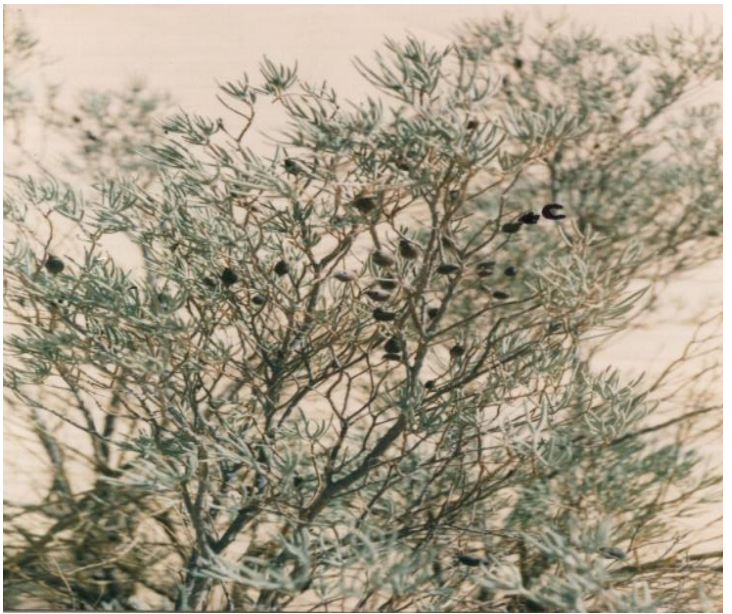

Fig.7 The fruits of Limoniastrum guyonianum are the capsules. 
According to Refs. [24, 25], Limoniastrum guyonianum is an endemic species of Sahara Northern and it is a Chamaephyte.

We suggest introducing L. guyonianum in different saline locality of Algeria due to the fact the selection of species for saline soils in Syria has been studied by Ref. [26] and the selection of wood producing species is treated by Ref. [27].

The halophyte vegetation established in these difficult environments must be able to withstand large variations in salinity, high salinities during sometimes several months, and prolonged and repeated sun exposure periods. It has by consequently developed physiological mechanisms of tolerance and resistance to salt, nutriments storage, vitamins and trace elements, and photoprotection. These properties osmoprotection and photoprotection find incosmetology applications and healthy fields.

On the other hand these plants which have the particularity to be grown without freshwater input (biosaline agriculture) may for some be improved in the field of food processing (food and feed) [28]. This work can be completed by detailed physiological and anatomical studies, to know the reaction and the tolerance of the plant to the salinity.

\section{Conclusion}

This work concerns an endemic species of the arid and salt zones of Algeria.

It shows some characteristics of a tree which survives in difficult conditions. It also represents an Algerian heritage to preserve and enrich plant biodiversity in Algeria. Finally, according to Tela Botanica (The Francophone Botanical Network 2017) there is no information about Limoniastrun gyuonianum, and this study will consolidate the research about its description and its ecology.

\section{Acknowledgments}

We thank the Directors of the Office of National Meteorology (ONM) (Oran) and the laboratory of pedology at Institute Technology of Agronomy (ITA) (Mostaganem) for their technical assistance.

\section{References}

[1] Higazy, M., Shehata, M., and Allam A. 1995. "Free Proline Relation to Salinity Tolerance of Three Sugar Beet Varieties.” Egypt. J. Agric.Res. 73 (1): 175-89.

[2] Aït Belaid, M. 1994. "Les systèmes d'information pour l'environnement: développement et formation." Géo Observateur 5: 61-9.

[3] Lieth, H., Moshenko, M., and Menzel, U. 1997. "Sustainable Halophyte Utilization in the Mediterranean and Subtropical Dry Regions." In Proceedings of the International Conferences on Water management Salinity and Pollution Control towards Sustainable Irrigation in the Mediterranean Region. Valenzano Bari, p. 209. 23-26 September.

[4] Hamdy, A. 1999. "Saline Irrigation and Management for a Sustainable Use." In Advanced Short Course on Saline Irrigation Proceedings, Agadir Morocco, pp. 152-227.

[5] Szablocs, I. 1994. "Prospects of Soil Salinity for the 21st Century." Int. Cong of Soil Sci. 1: 123-41.

[6] Claud, G., Malher, C., ClaudRemy, J., Berthelm, J., and Louis Morel, J. 2005. Solet Environnement. Paris: Dunod, pp. 609-25.

[7] Le Houerou, H. N. 1993. "Salt-Tolerant Plants for the Arid Region of the Mediterrannean Isoclimatique Zone." In Towards the Rational Use of High Salinity Tolerant Plants, edited by Leith and A AlMassoom. Vol. 1. Kluveracadem, pp. 403-22.

[8] Rozem, J., and Flowers, T. 2008. "Crops for a Salinized World." Science 322: 1478-780.

[9] Abdel Latef, A. A. 2010. "Changes of Antioxidative Enzymes in Salinity Tolerance among Different Wheat Cultivars." Cereals. Comm. 38: 43-55.

[10] Chamard, P. 1993. "Environnement et développement références particulières aux états sahéliens membres du CCILS." Rev. Sécheresse 4: 172328.

[11] Batanouny, K. H. 1993. Ecophysiology of Halophytes and Their Traditional Use in the Arab World Advanced Course on Halophyte Utilization in Agriculture, 12 Sept. Agadir, Morocco.

[12] Belkhodja, M. 1996. "Action de la salinité sur le comportement physiologique, biochimique, hormonal et recherche de marqueurs moléculaires chez la fève (Vicia faba L.)." These de Doctorat d'Etat ès Sciences naturelles, Université d'Oran (Algérie).

[13] LeFloch, E. 1983. "Contribution à une étude ethnobotanique de la flore tunisienne." Ministere de l'Enseignement Supérieur et de la Recherche Scientifique, p. 192. 
[14] Le Houerou, H. N. 1996. "Use of Fodder Trees and Shrubs (Trubs) in the Arid and Semi-Arid Zones of West Asia and North Africa: History and Perspective." In Fodder Shrubs Development in Arid and Semi Arid zones, edited by G. Gustave, M. Bounejmate, and A. Nefzaoui, Proceedings of Regional Workshop on Native and Exotic fodder Shrub in Arid and Semi arid Zones, 27 Oct.-2 Nov., Hammamet, Tunisia, pp. 9-53.

[15] Quezel, P., and Santa, S. 1962. "Nouvelle Flore d'Algérie et des régions désertiques méridionales." Tome 1, 2, Edition du Centre National de la Recherche Scientifique, Paris.

[16] Sauvage, C. 1961. "Etages Bioclimatiques." In Atlas du Maroc Notice Explicative, Section II, p. 44.

[17] Aubert, G. 1983. "Observation sur les caractéristiques, la dénomination et la classification des sols salés ou sols sodiques, Cash." ORSTOM ser. ped. Vol. $\operatorname{xxxn}^{\circ} 1$, pp. 73-8.

[18] Bridges, E. M. 1978. World Soils (2nd ed.). Cambridge: Cambridge University Press, pp. 95-7.

[19] Loz, J., and Matieu, C. 1990. Dictionnaire de science du sol (2nd éd.). Lavoisier, p. 266.

[20] Madani, D. 2008. "Relation entre le couvert végétal et les conditions édaphiques en zone à déficit hydrique." thèse de magister en sciences agronomiques université d' El Hadj Lakhdar Batna, Algérie.

[21] Halitim, A. 1978. Cours de Sciences du sol. Pédologie Général et Agropédologie. Tome 1. INA. Alger.

[22] Baize, D. 1988. Guide des analyses courantes en pédologie, choix expression, présentation, interprétation.
Paris: INRA, p. 172.

[23] Frontier, S., Pichod-Vial, D., Le prêtre, A., Davoult, D., and Luczak, C. H. 2004. Ecosystème, Structure, Fonctionnement, Evolution (3rd éd.). Paris: Dunod, p. 549.

[24] Ozenda, P. 1983. Flore du Sahara (2nd ed.). Paris: CNRS, p. 622 .

[25] Chenchouni, H. 2012. "Diversité Floristique d'un lac du bas-Sahara algérien.” Acta Botanica 37: 33-44.

[26] Sankary, M. N. 1984. "Species Distribution and Growth on Slat-Affected Land in Syria." In Proceedings of the Research for Development Seminar on "Forage and Fuel Production from Salt-Affected Wasteland”, Cunderdin, W. Australia. 19-27 May. In Reclamation and Revegetation Research in CV Malcolm, Principal Research Officer, Division of Resource Management, Western Australian Department of Agriculture, 1985.

[27] Midgeley, S. J., Turnbull, J. W., and Hartney, V. J. 1984. "Fuelwood Species for Salt-Affected Sites." In Proceedings of the Research for Development Seminar on "Forage and fuel production from salt-affected wasteland” Cunderdin, W. Australia. 19-27 May. In Reclamation and Revegetation Research, C.V. Malcom. Principal Research Officer, Division of Resource Management Western Australian, Department of Agriculture, 1985.

[28] Della Patrona, L., Duke, N., and Loubersac, L. 2010. Biodiversité des plantes halophytes herbacéesdes tannes de Nouvelle-Calédonie. (Ifremer LEAD/Nouvelle-Calédonie et Queensland University Australie) (Poster). 